\title{
Department of Energy's Waste Minimization Program
}

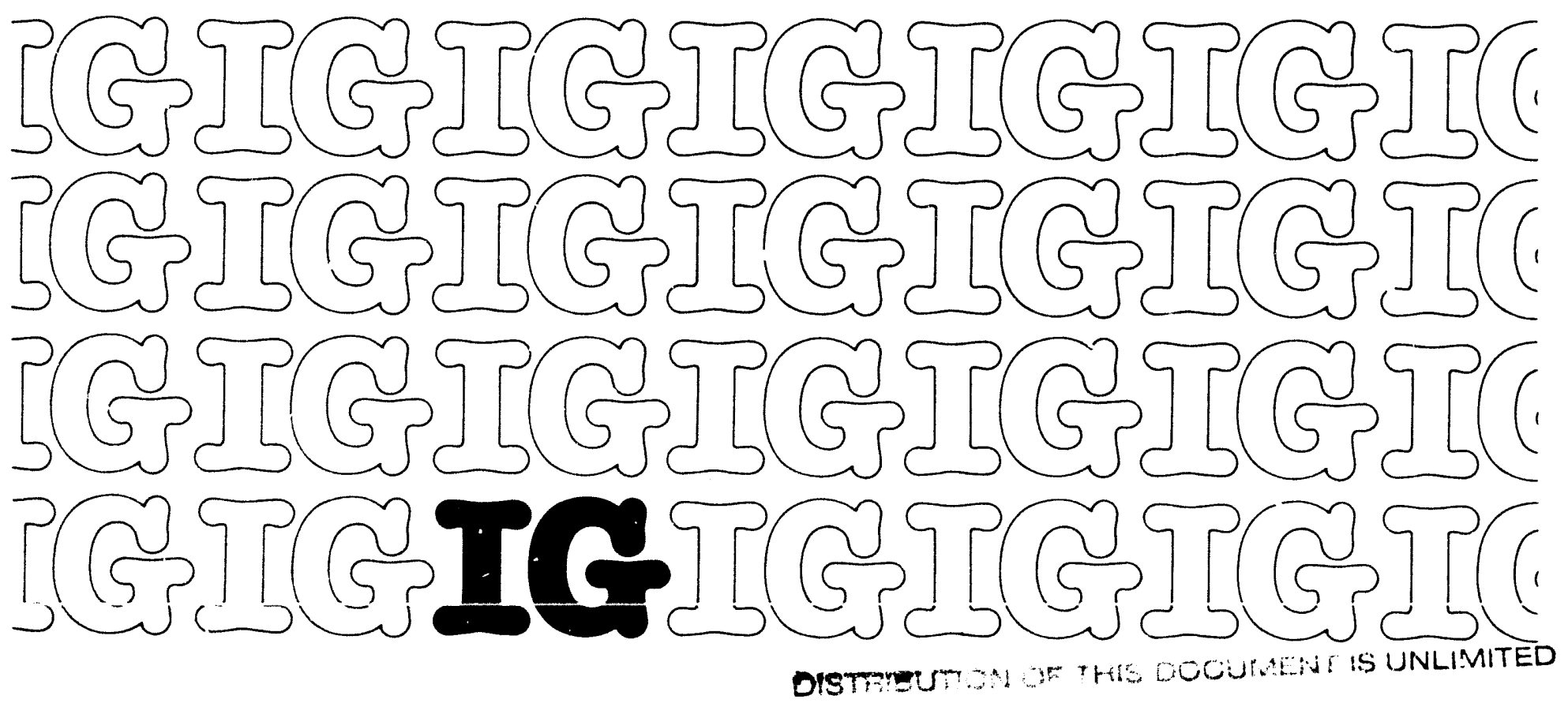


This report can be obtained from the U.S. Department of Energy

Office of Scientific and Technical Information P. O. Box 62

Oak Ridge, Tennessee 37831 
The Honorable John C. Layton

Inspector General

U.S. Department of Energy

1000 Independence Avenue, S. $W$.

Washington D.C. 20585

Dear Mr. Layton:

I have reviewed your audit report entitled "Department of Energy's Waste Minimization Program." I understand that the Assistant Secretary for Defense Programs (DP) and the Director of the Office of Environmental Restoration and Waste Management (EM) have already begun to implement the recommendations made in this report. I have directed them to complete doing 80.

Thank you for your assistance in helping the Department in its waste minimization efforts.

Sincerely,

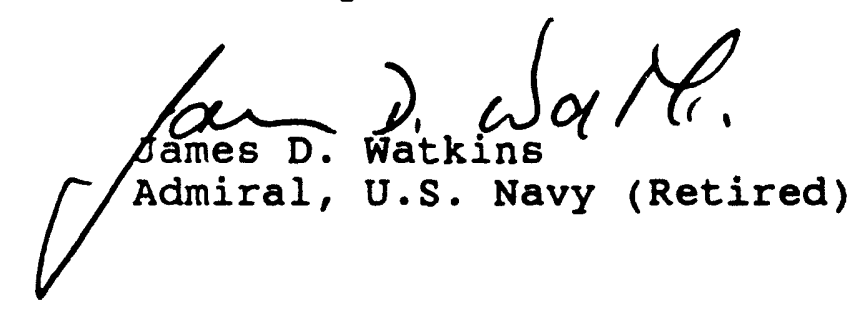




\section{memorandum}

DATE: SEP 031991

REPLY TO $\quad I G-1$
ATTN OF:

SUBUECT: INFORMATION: Report on "Department of Energy's Waste Minimization Program"

ro: The Secretary

BACKGROUND:

Attached is a copy of our audit report on reducing hazardous waste generated at Department of Energy (DOE) facilities and laboratories. The audit objective was to determine the adequacy of the Department's efforts to minimize the generation of waste.

\section{DISCUSSION:}

Waste minimization programs were examined at three weapons production facilities and two DOE weapons design laboratories. We reviewed current waste minimization policies, programs, plans, and projects.

The audit found that, while waste minimization progress is being made, significant opportunities to eliminate waste still exist. We believe the basic reasons we found for not implementing waste minimization opportunities--a lack of incentives, minimum program guidance, and uncertainty in funding--are applicable to the entire Departmentwide minimization program. Generating excessive amounts of waste will continue to expose the Department to acknowledged environmentally dangerous conditions that require costly remedial action.

The report describes six available opportunities for minimizing waste--three at Rocky Flats and three at the $Y-12$ facility--which, if implemented, could have immediate and substantial effect in reducing waste.

Management officials generally concurred with the audit finding and agreed to implement the recommendations.

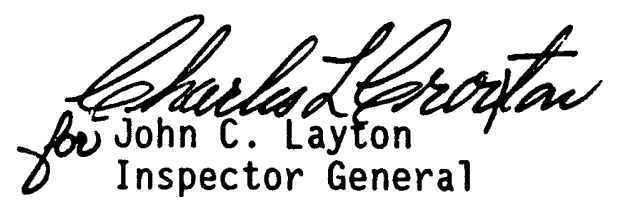

Attachment

cc: Deputy Secretary

Inder Secretary

Assistant Secretary for Defense Programs

Director, Office of Environmental Restoration and Waste Management 


\section{DEPARTMENT OF ENERGY'S \\ WASTE MINIMIZATION PROGRAM}

\section{TABLE OF CONTENTS}

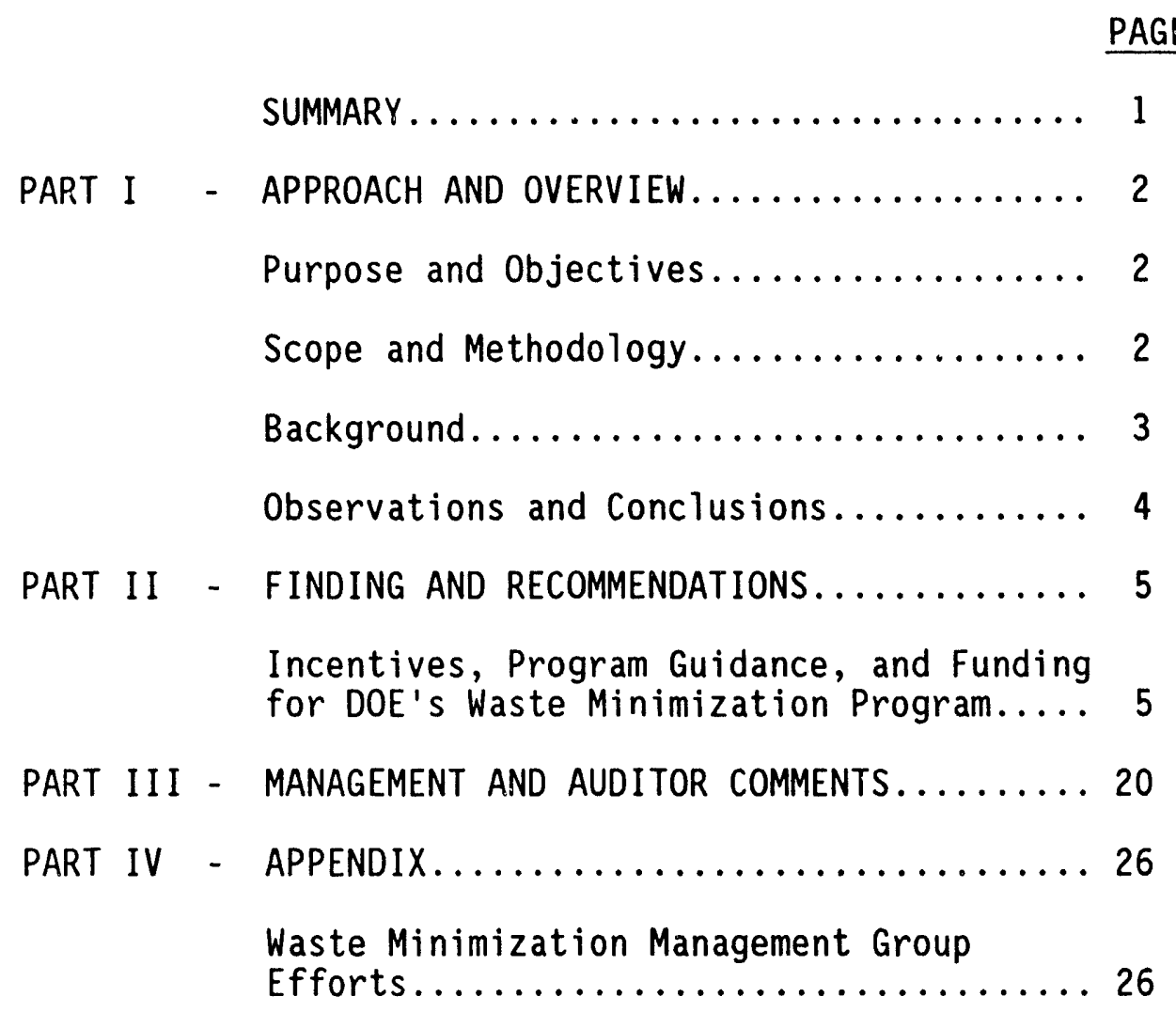


U.S. DEPARTMENT OF ENERGY

OFFICE OF INSPECTOR GENERAL

OFFICE OF AUDITS

DEPARTMENT OF ENERGY'S

WASTE MINIMIZATION PROGRAM

Audit Report Number: DOE/IG-0298

\section{SUMMARY}

Waste minimization, as mandated by the Congress, requires the elimination or reduction of the generation of waste at its source, that is, before it can become waste. This audit was made to determine the adequacy of the Department of Energy's (DOE) efforts to minimize the generation of waste.

Waste minimization activities were examined at three weapons production facilities--the Rocky Flats plant, which manufactures plutonium parts; 0ak Ridge's Y-12 facility, which produces uranium components; and the Savannah River site, which manufactures and loads tritium--and two DOE weapons design laboratories, Los Alamos and Sandia. At these sites, we reviewed current waste minimization policies, programs, plans, and projects.

The audit found that, while waste minimization progress is being made, significant opportunities to eliminate waste still exist. Waste minimization opportunities were not being implemented because of limited use of incentives, minimal program guidance, and funding uncertainties. Generating excessive amounts of waste will continue to expose the Department to acknowledged environmentally dangerous conditions that require costly remedial action.

The report describes six available opportunities for minimizing waste--three at Rocky Flats and three at the $Y-12$ facility--which, if implemented, could have immediate and substantial effect in reducing waste.

Management officials generally concurred with the audit finding and agreed to implement the recommendations.

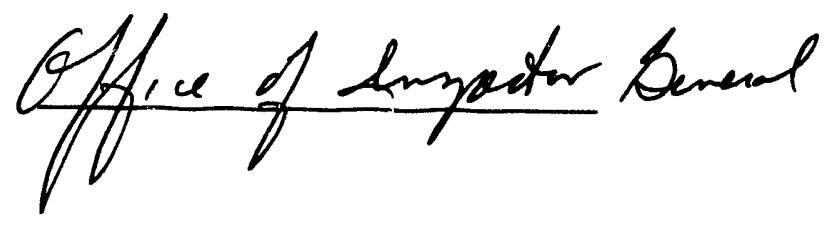




\section{PART I}

\section{APPROACH AND OVERVIEW}

\section{PURPOSE AND OBJECTIVES}

Waste minimization, as mandated by the Congress, requires the elimination or reduction of the generation of waste at its source, that is, before it can become waste. This audit was made to determine the adequacy of DOE's efforts to minimize the generation of waste.

\section{SCOPE AND METHODOLOGY}

The audit emphasized radioactive and other hazardous waste generation at DOE's nuclear weapons production plants and design laboratories. We included waste minimization activities and actions that can be taken now, in contrast to the long-range weapons complex modernization effort.

We reviewed waste minimization activities within the office of Environmental Restoration and Waste Management (EM), the Office of the Assistant Secretary for Defense Programs (DP), the Hazardous Waste Remedial Action Program Office, and the Waste Minimization Management Group (WMMG) in the Albuquerque Field office.

Waste minimization programs were examined in detail at the three largest nuclear weapons production facilities--the Rocky Flats plant, which manufactures plutonium parts; the $Y-12$ facility, which produces uranium components; and the Savannah River site, which manufactures and loads tritium--and two of DOE's weapons design laboratories, LOS Alamos and Sandia.

At these sites, we reviewed current waste minimization policies, programs, plans, and projects. We evaluated both funded and unfunded projects as well as funding sources. Six waste minimization opportunities were reviewed in detail. We also evaluated 57 proposed waste minimization related projects from Los Alamos' recent systemwide review of the weapons complex. Additionally, for the 211 waste minimization projects that the Albuquerque Field office had under consideration, we analyzed the various causes that were impediments to implementing waste minimization initiatives, not only in the weapons complex but throughout DOE.

The audit was made in accordance with generally accepted Government auditing standards for performance audits. It included tests of internal controls to ensure that DOE was complying with environmental laws and regulations and that waste minimization staffing was adequate to assure effective program implementation and control. Tests were made to the extent necessary to satisfy the scope of the audit. An exit conference was held on July 23, 1991, with DP and EM officials.

The firm of Irving Burton Associates, Inc., participated with the Office of Inspector General in the conduct of this audit. The audit was performed between April 1990 and February 1991. 
BACKGROUND

In DOE, there are three categories of regulated waste: radioactive, which emits harmful radiation; hazardous, which may be detrimental to human health or the environment; and mixed, which is a combination of radioactive and hazardous waste. Waste minimization can be accomplished by eliminating, substituting, or recycling the radioactive or hazardous waste material. It is achieved by giving source reduction the highest priority followed by recycling of waste materials as the second priority.

In making nuclear weapons over the past four decades, DOE has generated a large quantity of radioactive, hazardous and mixed wastes. Cold war demands during that period generally placed greater urgency on weapons research and production than on health and environmental concerns. As a result, waste storage areas were filled to near capacity, and the weapons complex was seriously contaminated and in need of long-term remedial action. While there were indications of waste minimization during this period, some of which provided significant results, there was little or no complex-wide coordination.

Recently, the dangers to health and the environment have created significant public awareness, and legislation has been enacted and funds dedicated to control and minimize the effects of radioactive and hazardous wastes. Current DOE policies require a greater emphasis on environmental, safety and health concerns than on production. The restrictions imposed by legislative and environmental concerns have already led to some DOE plant closures. Continued curtailment is likely if waste minimization actions are not undertaken expeditiously.

In response to these concerns, the Secretary of Energy, in a major shift of DOE priorities, announced his ten-point initiative in June 1989. "Environment, safety and health objectives," he said, "now take precedence over production objectives." Since then there have been substantial organizational and policy changes to further DOE's compliance with environmental laws and regulations. DOE's organizational structure was modified and funds were reprogrammed. Also, as the Secretary emphasized, line managers (managers of the program which generates waste) must recognize their full responsibility and accountability for compliance at the DOE facilities.

To provide a central focus on the Department's environmental problems, the Secretary established the Office of Environmental Restoration and Waste Management. This Office issued DOE's Five-Year Plan in 1989 which outlined a multibillion dollar waste management effort. The first annual update of the plan was issued in June 1990. Responsibility for DOE's waste minimization program was consolidated in EM, and partial waste minimization funding is included in the Plan. Funding for specific waste minimization operating improvements, not represented in the Five-Year Plan, is the responsibility of the weapons programs' line managers. DP established a complex-wide waste reduction program in March 1990 and appointed a waste reduction officer in April 1990. 
Since the Secretary's shift in priorities, progress has been made to put an effective program of waste minimization in place. During our audit, action had been taken to implement more comprehensive waste minimization programs at all weapons facilities. Guidance had besn developed for a model facility waste minimization plan--a plan that has been distributed to the field along with guidance for completing process waste assessments at all activities. Also, waste minimization goals throughout the weapons complex are under development and employee awareness programs are being pursueć.

Most recently, the Waste Minimization Management Group was established at the Albuquerque Field Office to fund, guide, and coordinate a portion of the waste minimization activities at DOE's weapons production plants and design laboratories. This Group was encouraged by DP to set aside process development funds for waste minimization, which was a recognition of line management's responsibility.

Notwithstanding these many positive initiatives, the test of any such program has to be whether it results in actual, measurable reductions in the amounts of waste being generated at the source. The audit found, as discussed in detail in Part II, that the Department still has a great deal to accomplish in bringing about the desired results. It must also ensure that good ideas are implemented expeditiously and on a Departmentwide basis. This report makes a number of specific recommendations to bring this about.

Unique program areas will also require a comprehensive approach to waste minimization. An excellent example is the disassembly of returned weapons. Over 200,000 separate components from at least 21 weapons systems must be disposed of over the next 5 years, according to a $Y-12$ study. Current disassembly facilities and procedures were not set up for a volume this large and, as a result, excessive quantities of waste will be generated.

We believe the need for a more comprehensive waste minimization program--to include greater use of incentives, more detailed program guidance, and improved funding--is symptomatic of the total systemwide problems. The absence of program staffing in EM reinforces this conclusion. Therefore, in addition to recommendations to DP, we included recommendations for the Director of EM, as program manager for waste minimization, to fully staff the waste minimization office and implement and followup on systemwide corrective actions. Management essentially concurred with the report and its comments, reflected in Part III, were responsive to all of the recommendations.

In our opinion, the absence of a comprehensive and effective waste minimization program and the absence of adequate staffing for waste minimization activities indicates internal control weaknesses which should be considered by management when preparing the yearend assurance memorandum on internal controls. Since our review was limited, it woluld not necessarily disclose all material internal control deficiencies that may exist. 


\section{PART II}

\section{FINDING AND RECOMMENDATIONS}

Incentives, Program Guidance, and Funding for DOE's Waste Minimization Program

\section{FINDING}

Federal, state and local laws require expeditious action to eliminate or reduce the generation of radioactive and other hazardous wastes. While waste minimization progress is being made, significant opportunities to eliminate waste still exist. Waste minimization opportunities were not implemented because of limited use of incentives, minimal program guidance, and funding uncertainties. Generating excessive amounts of waste will continue to expose the Department to acknowledged environmentally dangerous conditions that require costly remedial action.

\section{RECOMMENDATIONS}

1. We recommend that the Assistant Secretary for Defense Programs with advice and assistance from the Director, Office of Environmental Restoration and Waste Management:

a. For immediate impact in eliminating or reducing the generation of waste, identify and implement specific waste minimization incentives for line management (e.g., goal setting, management award fees, individual awards).

b. At the same time, establish a comprehensive waste minimization program for each field site so that:

(1) Incentives are recognized and fully applied in areas such as goal setting, management award fees, chargeback fees and employee awareness;

(2) Program guidance is developed for project selection criteria that includes priorities, economic analys is and impact of waste stream reductions; technology exchange within and between design laboratories and production plants; and tracking and followup on project completion and implementation; and

(3) Funds and funding sources are clearly identified to support projects that can have an immediate impact in eliminating waste generation; and implement, with dedicated funding, line management (programmatic) responsibility for waste minimization.

2. We recommend that the Director, Office of Environmental Restoration and Waste Management:

a. Expeditiously fill the Waste Minimization Manager position at 
DOE Headquarters and provide the supporting staff to fully activate the Waste Minimization Branch.

b. Improve and expand DOE waste minimization guidance to all Field offices and the contractor operated facilities.

c. Conduct onsite reviews of the waste minimization program at each field site and provide recommendation(s) for improvement to their waste minimization plans and programs through the appropriate management channels.

\section{MANAGEMENT REACTION}

The Offices of Defense Programs and Environmental Restoration and Waste Management generally concurred with the finding and agreed to implement all of the recommendations. Part III of this report includes detailed management and auditor comments.

\section{DETAILS OF FINDING}

\section{REQUIREMENTS FOR WASTE MINIMIZATION}

The Federal policy for waste minimization is contained in the 1984 Hazardous and Solid Waste Amendments to the Resource Conservation and Recovery Act (RCRA) of 1976. The Congress declared "...it to be the national policy of the United States that, wherever feasible, the generation of hazardous waste is to be reduced or eliminated as expeditiously as possible." According to RCRA, "Waste that is nevertheless generated, should be treated, stored or disposed of so as to minimize present and future threat to human health and the environment." RCRA's statements establish a hierarchy for managing waste, with the elimination of the generation of waste having priority over subsequent treatment, storage and disposal.

More recently, the RCRA position was reinforced by the Pollution Prevention Act of 1990: "Source reduction is fundamentally different and more desirable than waste management and pollution control... Pollution [i.e., waste] should be prevented or reduced at the source whenever feasible."

The Environmental Protection Agency (EPA) Manual for Waste Minimization Opportunity Assessments reflects congressional intent by defining waste minimization as source reduction and recycling, with the main goal to reduce or eliminate waste. To achieve this goal, the RCRA regulations require that waste generators inave a program in place to reduce the volume and toxicity of waste generated to the extent that is economically practical. The EPA manual describes a program in place as an organized, comprehensive, and continual effort to systematically reduce waste generation.

Other regulatory programs strongly encourage waste minimization actions, such as EPA's Land Disposal Restrictions, which restricts land disposal of untreated hazardous wastes. Because treatment is required before the waste can be disposed of, costs are substantially higher than without treatment. Also, permits issued by Federal or state regulators limil the DOE sites' capacity for waste treatment, storage or disposal. 
In addition to Federal, state and local laws governing environmental protection requirements, the Atomic Energy Act of 1954, as amended, governs radioactive waste. DOE policy for implementation of this law recognizes that the generation, treatment, storage, transportation, and/or disposal of radioactive wastes, and the other pollutants or hazardous substances they contain, shall be accomplished in a manner that minimizes the generation of such wastes.

DOE's waste reduction policy requires all DOE organizations to reduce the total amount of waste generated and disposed of by DOE operating facilities through waste minimization (source reduction and recycling) and waste treatment. This policy recognizes source reduction as the highest priority, recycling as the second, followed by treatment, storage and disposal and applies to all wastes: radioactive, hazardous, nonhazardous, and radioactive mixed wastes. 1/

The Department's waste minimization program objectives are to ensure that each DOE operating facility (1) organizes a comprehensive waste minimization program with goals and schedules; (2) develops a method for characterizing and tracking its waste streams; (3) identifies applicable methods and technologies for waste minimization; (4) develops employee training and awareness programs; and (5) complies with Federal and state regulations and DOE requirements for waste minimization.

\section{WASTE MINIMIZATION ACTIVITY}

With the Secretary's recent emphasis, DOE has made progress in implementing waste minimization programs, but more needs to be done. Our review disclosed that waste minimization opportunities at the production facilities throughout DOE's nuclear weapons complex were still not being implemented even though they could have an immediate and substantial effect in reducing waste.

\section{Opportunities to Reduce Waste at Rocky Flats Plant}

The Rocky Flats $\mathrm{Plant}$ makes nuclear weapons components using radioactive plutonium and other metals in the component fabrication process. This process generates radioactive transuranic waste, 2/ some of which contains hazardous material and hence is classified as mixed waste. The three examples of available waste minimization opportunities described below, if implemented, have the potential to reduce the radioactive transuranic mixed waste generated at Rocky Flats by roughly a third.

1/ From Waste Reduction Policy Statement, June 27, 1990, which consolidated various waste minimization, requirements in DOE Orders: (5400.1) General Environmental Protection Program, November 9, 1988; (5400.3) Hazardous and Radioactive Mixed Waste Program, February 22, 1989; and (5820.2A) Radioactive and Waste Management, September 26, 1988.

2/ Transuranic waste is any waste material contaminaced with radioactive elements heavier than uranium at levels greater than 100 nanocuries per gram. Typical waste forms include contaminated glassware, equipment, tools, rubber gloves, paper products, and clothing. 


\section{Bagless Transfer}

The process of fabricating nuclear weapons components at Rocky Flats requires that the work be performed within shielded enclosures called "glove boxes," which minimize the radiation exposure of the workers. The

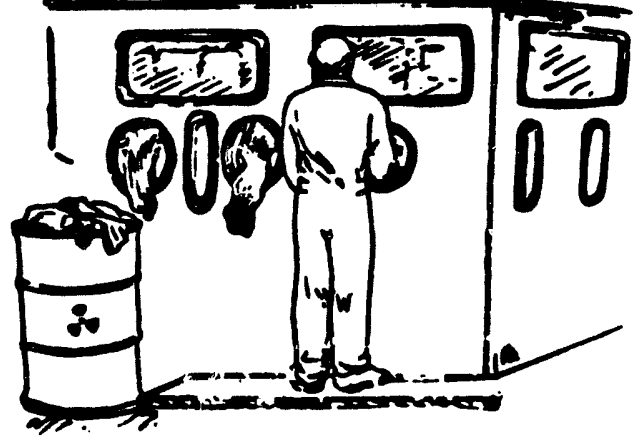

Typical Glove Box components are transferred between various glove boxes in order to complete each phase of the fabrication process. The transfer of radioactive materials between glove boxes is made in plastic bags, which also become radioactive through contact with the materials and must be disposed of after each use. The contaminated plastic bags account for the equivalert of about 400 drums of radioactive transuranic mixed waste a year and make up roughly 13 percent of the total waste in this category.

A 1998 Rocky Flats study entitled Bagless Transfer Feasibility Study recommended "fast track" implementation of bagless transfer technology. Bagless transfer utilizes a reusable metal canister in p?ace of the bags.

\section{Example of Three Step} Canister Application

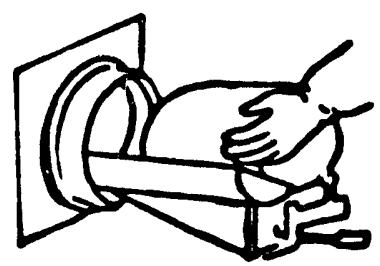

1 Insert Container

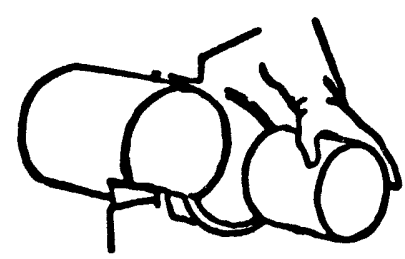

2 Objects Can Then Be Inserted/Removed

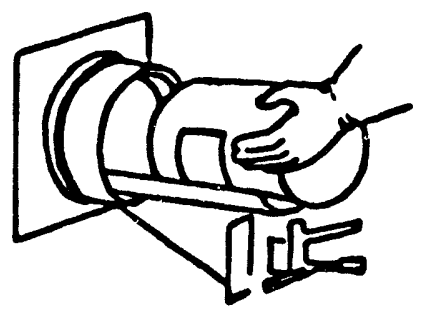

3 Container Removed

The study concluded that reusable canisters would eliminate the plastic bags as a source of waste. They also reduce the possibility for operator radiation exposure and are less costly. The study also stated that the bagless transfer method is being used successfully in nuclear facilities throughout Europe. Rocky flats personnel developed a project proposal to introduce the bagless technology at the plant, as part of a larger retrofit project, at an estimated cost of about $\$ 2$ million. This project was not put in DOE's Five-Year Plan, a) though "fast track" implementation was recommended in 1988 . Rocky Flats has deferred further work on the bagless transfer until Fiscal Year (FY) 1994. 


\section{Dry Machining}

Current techniques at Rocky Flats for the machining of weapons components from plutonium metal use coolant oil in the machining prccess. Solvents are then used to clean the oil from the machined parts and the recoverable plutonium scrap. This is a typical machine shop fabrication operation, except that it is dore inside glove boxes. The racioactive oils and solvents, after use, feed into a mixed waste streain at the plant.

In one prodiction building, the current process generates 240 drums of radioactive mixed waste each year, or roughly 8 percent of the total waste in this category.

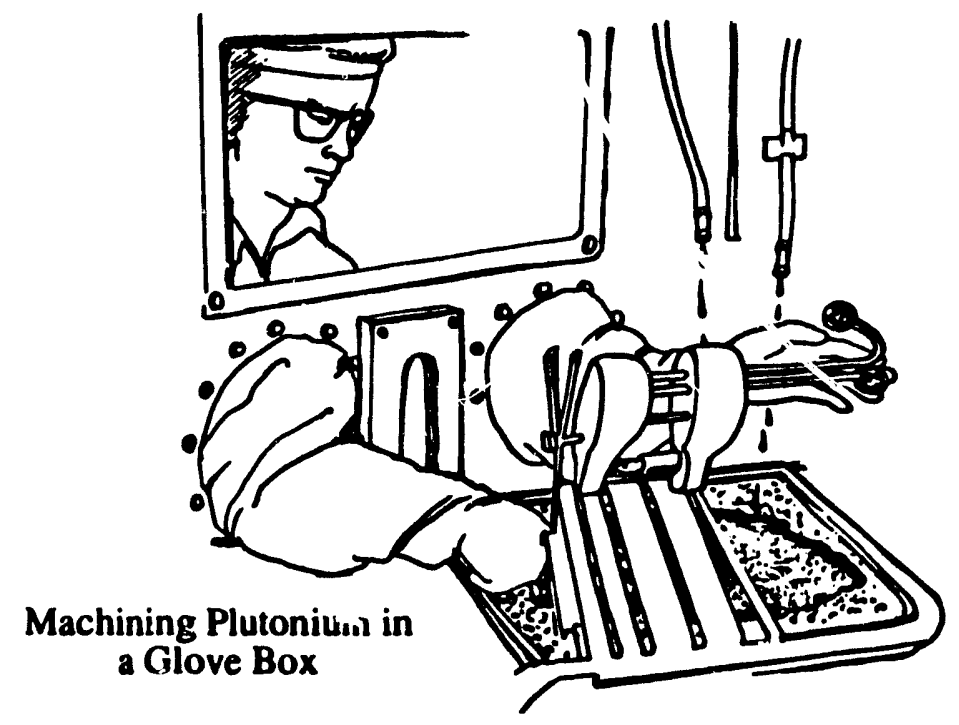

Los Alamos National Laboratory developed a proposal, C.y Machining of Plutonium, which could virtually eliminate the generation of radioactive mixed waste from the machining process. Dry machining systems have been successfully implemented by industry using newly developed ceiamic cutting tools and safety procedures to keep the machined parts from getting so hot that they could ignite a fire. Combustible elements, such as oxygen, are substantially eliminated from the atmosphere inside the glove boxes to avoid a iire.

Dry machining was successfully demonstrated by LoS $A$ lamos and has been used there since 1986. Los Alamos personnel estimated that it would cost $\$ 3.5$ million to develop the dry machining technology for Rocky Flats and, in 1990 , made a proposal to do so. Additional funds would also be required to modify production facilities at Rocky Flats. The proposal, however, lacked a cost/benefit analysis of its full potential to reduce waste. It was not included in DOE's Five-Year Plan.

\section{Vacuum Decontamination System}

Rocky Flats personnel currently hand clean the floors of its plutonium production facilities. The used, contaminated mops, wipes and towels are bagged and processed as radioactive waste, then temporarily stored awaiting final disposition at permanent storage facilities such as DOE's Waste Isolation Pilot Plant. Rocky Flats staff engineers estimated that in one plutonium production area alone this hand-cleaning system generates the equivalent of 400 to 600 drums of mixed radioactive waste annualiy, roughly 16 percent of the total waste in this category.

A vacuum decontamination system would virtually eliminate the generation of cleaning material wastes. The system is a single-person, stand-up method 
which employs a super-heated water, spray-vacium cleaning technique to remove loose surface radioactive contamination.

A powerful vacuum is used to create high air velocities to immediately remove the water after it strikes the surface. This type of vacuum cleaner has been used in industrial applications for a number of years. Compared to the waste from the current hand-cleaning method, waste from the vacuum system's filters would be negligible.

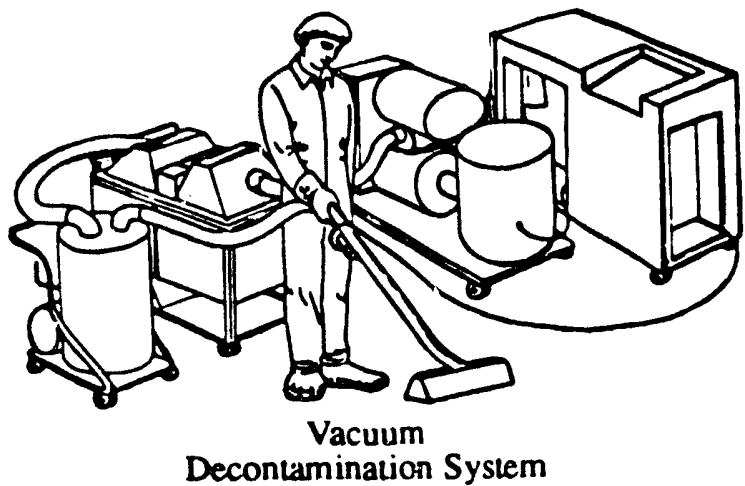

Rocky Flats bought a vacuum decontamination system about 2 years ago. It was to be initially used in nonradioactive areas and to later replace the prerent manual hand-clean procedure used in plutonium processing facilities. up to the time 0 ; nur site visit, however, the vacuum equipment had been kept in storage and i:ad not been used. This occurred because management had nct analyzed the system's waste minimization potential. Also, there had been no incentive for line management to followup to ensure timely implementation.

Opportunities to Reduce Waste at Oak Ridge's Y-12 Facility

$Y-12$ 's primary mission is to produce components for DOE's weapons program. The production process uses radioactive materials, primarily uranium, and chemicals considered hazardous by EPA. Three examples of available waste minimization opportunities at $Y-12$ are described below. All would significantly reduce radioactive and hazardous waste generations and relieve storage problems.

\section{Alternate Materials}

The Y-12 plant uses cloth wipes, mops, gloves, filters, laboratory coats, and other materials for cleaning, personnel protection, and manufacturing support. These materials become contaminated and generate large volumes of radioactive, hazardous and mixed waste.

Many of the contaminated materials are incinerated. In one processing area about 2,200 pounds of radioactive ash are generated annually. The ash residue must then be stored in expensive-to-maintain protective vaults. Contaminated material that is not incinerated must be stored in bulk form. In another $Y-12$ area, about 35,000 drums of contaminated bulk material (packing boxes, paper, mops, rags, filters, etc.) are generated--enough to cover an acre 6-feet high. The annual cost to process and move this waste into storage is $\$ 7.2$ million. Storage and monitoririg costs for this waste have not been determined but, under current regulations, will continue indefiniteily.

Y-12 plant officials stated that newly developed and improved "spaceage" cleaning and support materials are commercially available. These are, for example, plastic materials that resist absorbing contamiriants due to their hardness and newly developed gloves, coats, hats and other materials that can be cleaned and reused, not discarded after one use. When these alternate materials are eventually discarded, they are of such consistency that they can be burned or tightly packed to get much smaller ash or bulk residues. Plant 
officials estimate that ash residues could be reduced by 65 percent, and bulk waste could be reduced by 35 percent, with an estimated yearly savings of $\$ 2.5$ million.

The $Y-12$ plant developed a $\$ 7.5$ million proposal to identify, evaluate, adapt and demonstrate the best alternate materials to replace the materials now in use. The proposal did not include a cost-benefit analysis of the treatment, storage and disposal costs, or an overall estimate of the waste that would be reduced since all Y-12 divisions would be affected. This proposal was not funded locally or included in DOE's Five-Year Plan.

\section{Waste Segregation and Recycling}

Each year the uranium component metal forming and fabrication process at the Y-12 plant generates about 220,000 gallons of mixed waste. This waste stream is mainly radioactive water which comes from cleaning the equipment and the working area. The radioactive waste water flows into a common collection pit where it mixes with used oil from another waste stream. The mixed waste is then transported to $Y-12^{\prime}$ 's treatment center, processed, and placed in tanks for long-term storage. The annual treatment cost is $\$ 1.3$ million. The continuing monitoring and storage costs had not been calculated.

Process development personnel at $Y-12$ estimated that segregating and recycling the radioactive cleaning waste could cut mixed waste generation by 80 percent and reduce annual treatment costs by about $\$ 1$ million. Segregation could be done by building "containment curbing" to prevent the radioactive cleaning water from flowing into the collection pit and mixing with the used oil. The radioactive cleaning water could then be recycled several times, a procedure now precluded because of the oil contamination. Primarily because of a lack of funds, an assessment had not been made to evaluate this or other potential methods of minimizing this waste stream.

\section{Electrodialysis Reversal System in Steam Plant}

The $Y-12$ steam plant supports the plant heating, ventilation, air conditioning and manufacturing processes. To meet the plant's operating

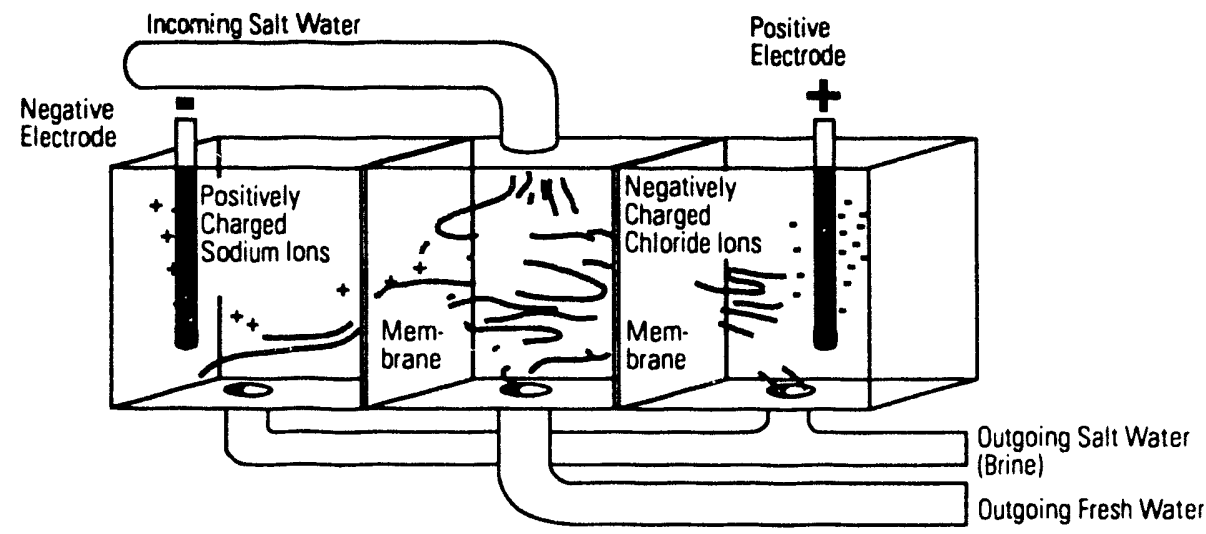

requirements, dissolved salts must be removed from the feedwater going into boilers. This salt removal now requires a large amount of chemicals, which 
produce strongly acidic waste water. The waste water is then treated to form a sludge which is buried in a Y-12 landfill. That process produces about 880 tons of sludge a year and discharges 322 tons of chemicals that ultimately flow into Tennessee's Clinch River. The plant has a permit for these discharges.

An electrodialysis reversal system is regularly used in commercial applications to remove dissolved salts from boiler feedwater. Electrodialysis uses electricity rather than chemicals to purify the water, thereby significantly reducing the amount of chemical waste produced in the process.

Changing from a chemical process to the electrodialysis reversal system would (1) reduce costs for chemicals, fuel, treatment, and disposal (the total savings in just the steam plant operating costs would amount to about $\$ 800,000$ a year); (2) decrease the potential for employee exposure to toxic substances because of the reduced use of chemicals and reduce by 80 percent the chemicals being discharged into the river; and (3) reduce the amount of sludge generated from 880 tons to 184 tons a year thereby saving 30,000 cubic feet of landfill space. At the current rate the plant will need a new landfill in 2 years at a cost of $\$ 10$ to $\$ 12$ million, plus the : gh operating costs caused by the need to continuously monitor the ground $w$ r near the landfill.

The Y-12 plant has a $\$ 3$ million proposal to implement the electrodialysis reversal system. At the time of our review, the project had not been funded. According to plant personnel, there is usually not enough money to fund waste minimization projects.

\section{Departmentwide Applications}

The technology and processes in these waste minimization opportunities can be applied at other DOE locations. For example, glove boxes are used and contaminated bags are generat' $₫$ not only at Rocky Flats but throughout the DOE weapons complex; thus, furthe applications for bagless transfer technology exist complex-wide. The procedure of hand-cleaning floors with mops, wipes and towels is also prevalent in all weapons production facilities--therefore, the use of the vacuum decontamination system has a broader application. Also, using alternative materials for cleaning and personnel protection should have applications and savings at all DOE weapons facilities. Y-12's electrodialysis reversal system could eliminate most chemical contamination in the steam plant's feedwater and have applicability to other similar DOE plants. To our knowledge, none of these waste minimization opportunities have been or are being considered for DOE-wide use.

\section{REASONS FOR LACK OF PROGRESS}

The specific reasons for not implementing these waste minimization opportunities involve at least three basic underlying causes: a lack of incentives, minimum program guidance, and the uncertainty of funding. These three causes are discussed below.

\section{Incentives For Waste Minimization}

We found few incentives for production managers to reduce waste. There was a lack of goal setting, very limited use of the management award fees, deferred use of chargebacks to tax the waste generators, and few employee 
awareness programs. Possible incentives include the establishment of quantitative goals, award fees to contractors, influencing personal and organizational attitudes through monetary performance awards, and charging operating departments (chargebacks) for the costs to minimize the waste they generate. Incentives, such as these, were not being effectively used. Emphas is is needed here to help overcome DOE's longstanding culture of putting production ahead of waste minimization.

\section{Goal Setting}

Meaningful local and DOE-wide waste minimization goals have neither been set, nor are measuring systems aviilable to record progress. This occurred because accountability for individual line managers has not been defined nor quantified and, at the sites we visited, specific goals had not been assigned to production building malagers or supervisors. As a result, goals were not being put in place at the point where reductions can actually be made.

DOE guidance calls for waste generators to set specific waste minimization numerical coals "even if information on waste generation forecasts is fairly imprecise." At Rocky Flats the vacuum decontamination. system may have been int:roduced and implemented if goals had been set and a line manager held accountable. However, even if goais were set, baseline data was not available to track the reduction of waste generation.

\section{Management Award Fee}

The opportunity to get top management's attention, on a systemwide basis, has been overlooked. Waste minimization was not uniformly recognized as a separate element when determining management's performance-award fee. An exception was at Savannah River where the operating contractor received a marginal rating for waste minimization during an interim performance review in early 1990. Waste minimization in this case was a separate performance element. Performance had been measured against discrete performance objectives and judged to be less than expected. Management's reaction was quick and responsive to reinforce and staff a more comprehensive waste minimization program. Otherwise, the low rating could lower the amount of the incentive fee. At the other production plants, the award fee structure did not recognize waste minimization as a separate performance element.

\section{Chargeback}

The principle of charging the waste generator for the cost of waste management is recognized by EPA and DOE as a direct incentive to minimize waste. DOE policy states, "Departments and managers should be charged for the waste management costs... [to] be motivated to avoid generating the waste..."

Chargeback systems to tax waste generators were in place or were being developed at various sites such as at the Savannah River site. Recently, however, the Savannah chargeback system, as well as others, was placed on hold with no firm dates for implementation. The financial incentive to fund local waste minimization projects, therefore, is not being realized even though EPA and DOE policy specifically support use of chargebacks. The application of a chargeback fee to local waste minimization projects is discussed on page 17 , "Local Use of Set-Aside Funds." 


\section{Employee Awareness Programs}

Efforts to achieve greater employee awareness of waste prevention and its benefits are spotty. The DOE Order 5400.1, issued in November 1988, described steps to improve employee awareness and required a program to be developed. The recent DOE policy statement recognized the importance of employee awareness even though its effectiveness is clearly diminished by the phrase: "Where time allows, the pollution prevention awareness elements should be included in the waste minimization program plan due May 9, 1990." (Underlining added.)

We did observe limited efforts to increase employee awareness. The operating contractor at the Savannah River site, for example, sponsors a Quality Award Program that recognizes individual waste minimization accomplishments. Also, site representatives were generally aware of the need to minimize waste, bui line managers or supervisors were seldom aware of improvements achieved in other areas.

\section{Program Guidance for Waste Minimization}

There was minimal program guidance to identify waste minimization projects, provide project selection sriteria such as an economic analysis and priorities, or to track project implementation at originating sites and for transfer elsewhere. None of the production plants we visited had a comprehensive waste minimization program. EPA states that a comprehensive waste minimization program should include clear program guidance; characterization of waste generations; waste minimization assessments to identify opportunities and costs; technology transfer where information can be exchanged within and between sites; and program oversight to periodically review effectiveness.

While DOE's waste minimization policy basically reflects EPA's outline, we found that program guidance to DOE field sites is far too general. Essential steps are neither detailed nor given appropriate recognition. In response to the DOE program guidance issued in November 1988, 38 field sites submitted waste minimization plans. A review of these plans by DOE's office of Waste Operations, in November 1990, concluded that "...all DOE facility waste mirimization program plans should be revised..." The plans were characterized as descriptions of current activities that could not be used as program plans. They were incomplete and lacked schedules, budgets and other elements of a comprehensive waste minimization program.

The poor showing of the plans can be attributed, at least in part, to the absence of a Headquarters DOE waste minimization program manager and supporting staff--five positions that EM has yet to fill. Headquarters has subsequently required the weapons complex site plans to be resubmitted and incorporate features in the recently issued Model Program Plan. Our site visits disclosed shortcomings in several key program areas. They are:

\section{Priorities}

At the Headquarters level, priorities used for projects in the Five-Year Plan virtually assure that little or no Plan funds are available for waste minimization projects. Waste minimization projects are normally a priority 3 (out of 4) and, at the current funding level, funds are generally limited to 
priorities 1 and 2. This prioritization has the effect of emphasizing the responsibility for line management's use of programmatic funds to achieve waste minimization goals and for the decisions made at the field sites.

At the field sites we visited, a waste minimization project selection process to set priorities was not in place. For example, the congressional intent and DOE policy to favor waste elimination over recycling or waste treatment should be evident in any description of priorities and a key factor in project selection. It was not. To illustrate, the dry machining project, currently being considered for special funding by the Albuquerque Field Office, will eliminate the need for machine coolants and solvents at the Rocky Flats Plant. Simultaneously, Rocky Flats has approved a $\$ 3$ million project to recycle the machine coolants and solvents. In addition, the Rocky Flats Solvent Elimination Task Team plans to eliminate use of the primary coolant, carbon tetrachloride, by 1992. These three approaches to minimize the same waste stream should have been analyzed, compared and prioritized as part of the decision making process. This was not done.

\section{Economic Analysis}

Among the more than one hundred waste minimization proposals we reviewed, none had an economic analysis to quantify the payback in terms of reduced waste and the savings in operating costs. We also noted this was not a requirement in the Headquarters format for project proposals (i.e., Activity Data Sheets). However, this is information that is vital in making resource decisions. For example, for the three waste minimization projects we examined at Rocky Flats (bagless transfer, dry machining and the vacuum decontamination system), we applied waste stream data provided by Rocky Flats personnel. The data showed that about one-third of the radioactive transuranic mixed wastes could be eliminated by these projects. But that analysis was absent from the Rocky Flats evaluations.

Also, at the Los Alamos National Laboratory, we reviewed a comprehensive study of 57 critical safety, health and waste minimization actions that needed to be taken during the next 5 years. $3 /$ The cost of implementing these projects was over a half billion dollars. The potential savings paybacks, though, were not developed and little action had been taken at the time of our review.

\section{Waste Stream Characterizations and Assessments}

The information provided by waste stream characterization and process assessment forms the basis for developing comprehensive plant waste reduction plans, annual budgets, and input to the Five-Year Plan. In our visits we observed only one site where a site-wide waste stream characterization analysis was being completed--at Rocky Flats. This is the foundation for subsequent waste assessments and setting specific reduction goals. But even in this instance there were no specific plans to initiate the next step, waste minimization assessments. Headquarters has recently distributed a model for conducting Process Waste Assessments (PWA); this is a noteworthy step since it will add consistency to the site programs.

3/ Modernizing Nuclear Weapons: Design for ES\&H [environment, safety and health] and Waste Reduction Proposals, March 29, 1 S90. 


\section{Technology Transfer}

In none of the six waste minimization opportunities reviewed or the 57 Los Alamos proposals did we find systems or plans for implementing the ideas at any other DOE locations. Communication within and between both the design laboratories and the production plants is in great need of improvement. For instance, dry machining is standard operating procedure at LoS Alamos (a research and development laboratory) but not at Rocky Flats (a production facility) even though machining principles are the same at each activity. Clearly, the vacuum decontamination system could be used throughout the weapons complex.

\section{Followup and Implementation}

The followup system for waste minimization projects we observed at the production sites we visited was not well organized or did not exist. The bagless transfer and vacuum decontamination system projects at Rocky Flats are examples of the absence of effective followup. Followup, to ensure implementation of waste minimization opportunities, is needed not only at the originating activity, but at other DOE activities that could benefit from the improvements.

\section{Funding for Waste Minimization}

The third underlying deficiency inhibiting the implementation of specific waste minimization actions is the uncertainty of funding sources and the competition for funds. At the plant sites, we found that waste minimization funding priorities and well-defined channels to fund project requests were lacking. This condition introduced unnecessary obstacles and hindered implementation of the projects we reviewed.

\section{Uncertainty of Funding Sources}

Customarily, waste minimization projects were funded from program. operating funds, much like other projects to improve the manufacturing process. When EM was established to remedy the broad environmental concerns facing DOE, funding was reprogrammed for EM's mission and to support the FiveYear Plan. Now, field sites obtain project funding for environmental restoration and waste management from EM; this includes funds for research and technology development to further waste minimization.

The changeover in funding responsibility has caused a certain amount of confusion at the field sites: Should the project request be submitted for EM sponsored funding, DP funding, or should it be a local determination to use program funds? When the "wrong" budget channel was used or furiding was not available, project approval was delayed a year or more. This was the case in several of the projects we reviewed, such as alternate materials.

The line manager, using programmatic funds, is responsible for waste minimization within the manufacturing process. This separation of funding sources becomes fuzzy when, for example, EM will fund a waste minimization project to satisfy a regulatory compliance--because compliance is also a part of EM's mission. This occurred at Rocky Flats when EM funded the waste characterization study (over $\$ 2$ million) that otherwise would be considered 
the waste generator's responsibility. In addition, it is difficult to draw the line between EM's research and technological support in contrast to the line manager's responsibility, particularly when two different sites, such as a laboratory and a plant, are cooperating on a joint project. At each of the sites we visited, personnel acknowledged their source of waste minimization funding was confusing.

\section{Competition for Funds}

Local use of program funds for waste minimization projects compete with other projects for funding. We noted during site visits that there was no local set-aside of funds and little recognition of priorities to reflect the waste generators' responsibility to minimize wastes. Some of the opportunities we identified, such as the bagless transfer, electrodialysis reversal system, and waste segregation and recycling illustrate these conditions. None of these projects competed successfully with other projects. As pointed out by a plant representative, if there is no "driver"--such as a compliance issue with EPA-- the waste minimization project will not be funded, even though waste minimization, in general, is a compliance issue.

\section{Waste Minimization Management Group Efforts}

The Albuquerque Field Office, with support from DOE Headquarters, recently established the Waste Minimization Management Group to fund and coordinate waste minimization projects among the weapons production plants and the design laboratories. About $\$ 42$ million (FY 1991) has been set aside for 76 projects and similar set-asides are planned in subsequent years. This initiative is a positive illustration of DOE's policy to apply operating funds to waste minimization. However, it also illustrates problems in funding joint laboratory plant projects, inconsistent Headquarters funding support, and the absence of plant line-management in this process. These problems are discussed further in the Appendix to this report.

\section{Local Use of Set-Aside Funds}

To more completely implement the Secretary's policy of line management responsibility and application of programmatic funds to minimize waste, we believe the concept of a fund set-aside--that is, setting aside a percentage of operat in funds or use of chargebacks to accomplish the same purpose--has application at local sites. Programmatic funds are now being spent on waste minimization projects, but the field sites could not tell us how much. These funds could be placed within the framework of a comprehensive site-wide waste minimization program, based upon a chargeback amount determined by the waste generated or improvements required; and, more importantly, these funds would be subject to the discipline of an organized waste minimization program. This action, in turn, could resolve some of the funding problems we identified that may have inhibited local adoption of available technologies to minimize waste.

\section{IMPACT OF WASTE GENERATION}

Radioactive waste requires unique care and is expensive to handle, ship and store. Similarly, use of hazardous materials requires costly treatment and disposal processes. The overall costs to store, treat and dispose of DOE wastes have never been measured precisely. DOE's Five-Year Plan estimate 
exceeds $\$ 30$ billion for clean-up and waste control. 4/ Without a comprehensive waste minimization program, DOE will continue to generate unnecessary waste, which will add to those costs and increase environmental risks and possible plant shut-downs.

DOE is continuing to generate waste at a rate that far exceeds the capacity of its treatment facilities. The equivalent of about 460,000 drums of mixed waste are generated annually, but the available treatment capacity is only equivalent to about 76,000 drums, or 17 percent. This 83 percent treatment shortfall will add 384,000 drums each year to the 1.7 million drums now in storage until new facilities are constructed.

During this audit, we found that implementation of three projects would cut radioactive waste generation at Rocky Flats by about 37 percent--13 percent with bagless transfer, 8 percent with dry machining and 16 percent with the vacuum decontamination system. Also, operating costs would be reduced, as would the personal risks to radiation exposure.

While we could not make an overall estimate of the total waste reductions for the three technologies we reviewed at $Y-12$, it is clear the reductions in the thousands of drums of contaminated radioactive materials and the hundreds of tons of hazardous chemicals and sludge would impact

significantly on the storage limitations and related costs at the $Y-12$ plant.

EPA states that "there is increasing evidence of the economic and environmental economic benefits to be realized by reducing waste at the source rather than managing such waste after it is produced." In its Five-Year Plan, DOE estimates that millions of dollars can be saved with the introduction of waste minimization technologies. In addition, for the projects we reviewed at $Y-12$, an estimated annual savings of at least $\$ 4.3$ million were evident. Also, for the Rocky Flats projects we reviewed, the annual savings in waste processing costs would be at least $\$ 1.7$ million.

Departmentwide Implications

This audit focused upon waste minimization at DOE's weapons complex sites. However, we also obtained an awareness of the program's effectiveness at the other DOE sites.

The November 1990, DOE review of 38 facility and Field office waste minimization plans cited 12 recommendations to improve waste ininimization plans and programs, including such needs as a strong management commitment, changes to the budget process, and collection and use of waste stream data. 5/ Also, another assessment of DOE's program developed systemwide observations, such as low program priority, lack of standardized approach,

4/ The U.S. General Accounting Office estimates that it will cost over $\$ 100$ billion to upgrade facilities to meet environmental standards, decontaminate and decommission unused facilities, dispose of radioactive wastes that have been stored for decades, and clean up contaminated ground water and soil.

5/ Analysis of Department of Energy Waste Minimization Plans, November 1990; prepared for DOE Office of Waste Operations, Division of Technical Support,
EM-35. 
undefined budget responsibilities, limited or no information transfer between sites, and not filling the Headquarters staff positions for the waste minimization program. $6 /$

We believe the various causes we identified--need for greater use of incentives, more detailed program guidance, and improved funding--are applicable to the entire DOE-wide waste minimization program. Therefore, EM, as the program manager for waste minimization, should implement and followup on systemwide corrective actions.

6/ DOE Waste Minimization Program Assessment, January 1991; prepared for DOE, Office of Waste Operations, Division of Technical Support, EM-35. 


\section{MANAGEMENT AND AUDITOR COMMENTS}

Defense Programs' Deputy Assistant Secretary for Military Application, and the Associate Director, Office of Environmental Restoration and Waste Management, generally concurred with the finding and agreed to impiement the recommendations. Management comments and our responses follow.

Management Comments. DP and EM expressed concern that the audit observation on opportunities being routinely passed up may not be representative since it is based upon specific examples from only two sites, $Y-12$ and Rocky Flats.

Auditor Comments. We feel that our audit scope supports our conclusion that significant waste minimization opportunities are being overlooked throughout the weapons complex and that DOE's program continues to lack sufficient incentives, program guidance and funding. The purpose of the audit was to examine current conditions, analyze the contributing causes, and to recommend appropriate corrective actions. To do this, we went to the three weapons production plants that generate the major portion of DOE's radioactive and other hazardous wastes. We examined the 57 waste minimization related projects from Los Alamos' recent systemwide review of weapons facilities. We also reviewed the 211 waste minimization projects included in the recent Albuquerque Field Office initiative.

The six projects examined in detail at the Rocky Flats and Y-12 plants were considered starting points for our analysis, which were then corroborated by our reviews of the waste minimization projects at Los Alamos and Albuquerque. We found that the projects being developed and reviewed by both Los Alamos and Albuquerque were experiencing the same implementation problems as the projects examined at Rocky Flats and $Y-12$. Our focus at the Savannah River plant, the third production plant we visited, was on its overall program and the impact of a marginal rating on the management award fee, not on overlooked opportunities.

Management Comments. DP stated that, prior to 1990 , waste minimization in the weapons complex was done on an ad hoc basis with some sites doing well and others not. However, it stated that a great deal of effective waste minimization activity still occurred despite any deficiencies in DOE's waste minimization program. Future pollution prevention activities in the weapons complex will reflect the continuing evolution of a DOE-wide pollution prevention program, coordinated and led by DP. Activities will reflect the overall program as well as individual site initiatives.

EM siated that the Office of Inspector General (OIG) report presents information that will be useful in managing DOE's waste minimization program. The DOE Headquarters and program support offices were already aware of some of the deficiencies mentioned in the OIG report and were taking steps to correct them. 
Auditor Comments. We recognize that, in the past, there have been individual or noteworthy accomplishments, and some of the production sites or weapons laboratories have been more active than others in waste minimization. However, we believe these are exceptions and more to the credit of local management than to the influence of Headquarters. Our conclusiors were further supported by recently completed independent studies cited in Part II of this report. Our analysis as well as these other independent studies identified causes that are systematic in nature, all of which call for Departmental level corrective actions.

Management's recent initiatives, which are recognized in Part I and II of this report, are positive steps. Also, its pollution prevention plans for the future are responsive to the report. Specific DP and EM actions on our recommendations follow.

Recommendation 1.a

Management Comments. DP agreed with Recommendation 1.a and stated that systemwide assessments should be completed and appropriate waste minimization opportunities implemented. Process Waste Assessinents were recently required by DP. All sites have been reminded to use incentives such as goal setting, award fees, and individual awards to ensure completion of PWA's and implementation of appropriate options. The specific waste minimization opportunities cited in the report will be evaluated and compared with the importance of ongoing activities.

EM agreed and stated that it will work with respective facilities on implementing, if applicable, the waste minimization opportunities identified in the report.

The Albuquerque Field office also agreed with the recommendation and indicated that goal setting and incentives are part of the waste minimization plans currently under revision by the plants and laboratories, and the award fee process incorporates waste minimization plans and initiatives.

Auditor Comments. Management's action is responsive to the recommendation. We would emphasize that this recommendation is directed to waste minimization actions which are within "state-of-the-art" technology and can have an immediate impact.

Recommendation 1.b

Management Comments. DP agreed with Recommendation $1 . \mathrm{b}$ and stated that a comprehensive Headquarters' waste minimization program is in place and guidance for establishing comprehensive site waste minimization programs has been distributed to the field offices. All sites are developing revised waste minimization plans. This planning effort will bring a measure of consistency to pollution prevention activities across the weapons complex; the revised plans will be submitted by May 31, 1991 .

The Albuquerque Field Office also concurred and stated that Process Waste Assessment and Waste Minimization plans are currently being revised and updated to conform to the model guidance provided by Headquarters.

Albuquerque will ensure that schedules in these plans are aggressive and quantitative goals are set by each plant and laboratory. Albuquerque is 
setting up a project control system to track funding, including waste minimization. Albuquerque plans to monitor all waste minimization activities. Albuquerque also conducts quarterly waste operaicions meetings for all the plans and laboratories. These meetings provide for information exchange and technology transfer and include waste minimization. DP provided the following specific comments on Recommendation l.b.

\section{Incentives}

DP agreed with the recommendation to recognize and fully apply incentives and have already begun to implement this policy. An upper management training session will be conducted for DOE and contractor senior weapons complex site managers with specific focus on goal setting, award fees, chargeback systems and employee incentives.

Goal setting. DP recognized that goal setting must be accomplished and Headquarters is planning further guidance and workshops on this issue. White many source reduction options have already been implemented, a set of weapons complexwide goals for pollution prevention will be developed and published and put in place by August 19S1. Hazardous materials/waste tracking systems are also being developed at several of the sites. Implementation of these tracking systens is anticipated for 1ate FY 1991 and 1992. These tracking systems will assist in waste minimization opportunity identification and hazardous materials management.

Management Award Fee. DP agreed that management award fees are an excellent incentive tool in producing an effective waste minimization program. Headquarters has been using award fees as an incentive for waste minimization/management for several years. A Secretarial Notice will be proposed to fociss on waste minimization and direct Field offices to further strengthen the program objective for waste minimization in cost-plus-award fee determinations.

Chargeback. DP agreed and recognized that a chargeback/fee system can be extremely effective in minimizing the generation of waste if the generator is provided an incentive which he can directly use. To be effective within the DOE weapons complex, a chargeback/fee system must allow waste minimization savings to be used within the line management organization as it sees fit. DP's Office of Military Application is studying thi feasibility ci setting up a fee or tax system within its line management to assist in funding waste minimization projects.

Employee Awareness. DP supported this and stressed that waste minimization has been developed into sitewide focus by extensive use of employee training programs and newsletters.

\section{Program Guidance}

DP acknowledged, as recognized by the report, the majority of site waste minimization plans reviewed by $E M$ were inadequate. As a result of this, more detailed guidance was provided including a model facility waste minimization plan. Additional program guidance has also been developed and promulgated for completing process waste assessments; it also contained guidance on setting priorities and using project selection criteria. This included worksheets for 
completing economic analysis and calculation of waste reduction. The following additional comments were provided.

Priorities. Waste minimization project prioritization has been addressed by giving guidance for developing a comprehensive waste minimization program, implementing process waste assessments, and establishing review groups such as the Waste Minimization Management Group by the Albuquerque Field office.

Economic Analysis. The PWA Model Plan guidance contains worksheets to assists sites in completing economic analysis. Estimations on the amount of waste which could be reduced and the payback period for process improvements are a part of conducting PWA's.

Waste Stream Characteristics and Assessments. All sites have begun PWA's as a result of specific DP guidance in a September 25, 1990 memorandum. PWA's are detailed analyses of processes in which waste streams and the operations that use and produce them are characterized and analyzed in detail. All sites will continue performing PWA's of priuritized waste streams/operations during FY 1991 and they will be carried out with a consistent methodology.

Technology Transfer. Technology transfer has been initiated and has been ongoing for some time between design laboratories, production plants, and the private sector. However, more active technology transfer mechanism is needed. This can be accomplished by field offices requiring sites to share ideas and solutions to waste minimization opportunities. To make this more active, DP has instructed field offices to increase incentives for technology transfer. The following actions are also being considered: specific elements relating to technology transfer to be added to cost-plus-award fees; and employee awards and performance evaluation to include elements for technology transfer actions. With more active participation by sites, existing mechanisms such as workshops and electronic bulletin boards can be more effective. In support of this, a complexwide newsletter (to facilitate technology and information transfer) will be initiated by DP in April 1991.

Followup and Implementation. Tracking of waste minimization project completion and implementation has been initiated. A semiannual inventory of the DP waste minimization program was begun in November 1990. DP will also direct Field offices to develop and implement a standard reporting system which will be closely monitored by Headquarters.

\section{Funding}

Management stated that waste minimization funding is currently being addressed by EM and DP to clarify funding procedures. When this guidance policy is developed it will be distributed to the sites. DP recognized that funding for waste minimization is unclear. DP has proposed a specific line item activity in the FY 1992 budget to emphasize waste minimization initiatives which would be carried in future EM budgets but executed by DP. EM at the senior staff level has agreed to this proposal. Additional commencs were provided for:

Funding Sources. Headquarters DP has initiated a concerted effort to develop a clear policy of funding. Landlord responsibility has been 
assigned by facility. Funding for projects will be the responsibility of the respective landlord entity (EM or DP). DP-20 will use its site action teams to ensure that projects and funding sources are appropriately identified.

Competition For Funds. Headquarters is also pursuing utilizing an internal chargeback or fenced funding system for appropriate waste minimization projects. In cases where production projects involve regulatory compliance as a driver, or if research and development is required, Headquarters (EM) will provide funding for those waste minimization projects.

Albuquerque's Waste Minimization Management Group. This Group has developed priorities and established funding levels for many waste minimization projects. Needed research and development has been identified and some of that (research \& development) is already underway; more of it will be funded during FY 1991. Twenty-five percent of Albuquerque's FY 1991 Process Development budget has been "fenced" to support this R\&D and EM has contributed $\$ 17$ million in support of this R\&D.

Auditors Comments. Management action is responsive to recommendation 1.b, and indicated a number of actions that have already been initiated. We stress that the interrelationship of all the elements of a comprehensive waste minimization program is as essential as each separate element.

\section{Recommendation 2}

Management Comments. EM agreed with Recommendation 2 and provided the following comments:

Recommendation 2.a. Action is under way to fill the Waste Minimization Program Manager position within the Division of Technical Support in the Office of Waste Operations. Additional staff for the Waste Minimization Branch are also being sought.

Recommendation 2.b. Information from this report will be useful in developing a more effective complex-wide waste minimization program. Management will specifically focus on developing clear guidance on goal setting, funding, and reporting waste minimisation activities. Management added that guidance for establishing a more comprehensive site waste minimization program is forthcoming. Specifically:

- A Model Facility Waste Minimization Plan and Process Waste Assessment guidance have been developed and distributed to field office waste minimization coordinators.

- EMi rlans to coordinate with the other DOE Principal Secretarial Offices in the design of a chargeback system that will foster waste minimization.

- EM will continue to improve the electronic bulletin boards and semiannual workshops to increase technology transfer. EM will also work with all Principal Secretarial offices to increase participation by sites in technology transfer and to establish a standardized reporting system for tracking and followup of waste minimization project completion and implementation. 
-- EM has begun an effort to develop a clear policy of funding for waste minimization.

Recommendation 2.c. The recommendation for EM to conduct onsite reviews of the waste minimization programs is under consideration. The appraisal approach has yet to be determined.

Auditors Comments. Management's actions are responsive to Recommendation 2. Regarding Recommendation 2.C, we believe EM should recognize program oversight and appraisal as an inherent responsibility of the program manager; EM's approach can also recognize and support the program managers' line responsibility to conduct self appraisals. 


\section{APPENDIX}

Waste Minimization Management Group Efforts

The responsibilities of the Albuquerque Field office include management of DOE's Process Development funds for seven weapons production facilities. The Process Development budget is about $\$ 100 \mathrm{million}$, and is a part of DOE's broader $\$ 2.3$ billion Production and Surveillance budget. Recent Albuquerque efforts to coordinate waste minimization among these plants, and include DOE's weapons laboratories, resulted in establishing the Waste Minimization Management Group. Albuquerque set aside about 25 percent of the Fiscal Year 1991 Process Development budget for waste minimization projects. Informal support was evident from Headquarters (DP-20). WMMG also established a budget call (211 project proposals were submitted for $\$ 155$ million), drafted project selection criteria and $\mathrm{planned}$ to conduct follow-up for funded projects. About 76 projects were selected for funding at the production plants and the laboratories. Of the $\$ 42$ million cost, $\$ 16$ million was for laboratory collaboration.

We believe this action illustrates implementation of the DOE policy to apply operating funds to waste minimization, but it also surfaced problems: funding joint laboratory-plant projects, inconsistent Headquarters funding support, and the absence of plant, line-management in this process.

Funding Joint Laboratory-Plant Projects. Albuquerque set aside about $\$ 26$ million for 76 waste minimization projects, anticipating additional funding from Headquarters to cover the total cost of $\$ 42$ million. This additional EM funding was required because (1) EM funds Technology Development waste minimization projects and (2) Albuquerque's Process Development funds (the source of the $\$ 26$ million) are restricted to use at the production plants--a number of these projects require laboratory collaboration. This process is uncertain because Albuquerque must subsequently negotiate with the EM staff to obtain the supporting funds for the laboratory's collaboration and cumbersome because separate lab and plant project statements must be approved and thereafter, coordinated and monitored.

Inconsistent Headquarters Support. Funding for DOE's defense programs is the responsibility of the Assistant Secretary for Defense Programs. Two Deputy Assistant Secretaries monitor the major portion of these funds, DP-10 for Nuclear Materials and DP-20 for Military Applications. As just described, DP-20 has supported the Albuquerque initiative, including a set-aside of operating funds. DP-10, on the other hand, has not supported waste minimization with a similar Headquarters commitment or set aside of operating funds.

Review by Line Management. An uncertainty has been introduced into the Waste Minimization Management Group process by the absence of $\mathrm{plant}$ line management to review and subsequently use the results of the $\$ 42$ million to waste minimization. These projects are predominantly multi-year developmental projects that will result in a proposal for plant management to modify the production process. However, there is no defined role for line management to review, comment or commit implementation funds to modify the production 
process while the project is on-going. At Rocky Flats, for example, their Solvent Elimination Task Team's goal is to eliminate the use of carbon tetrachloride in the plutonium processing area by 1992. This could argue against modification anticipated from the Dry Machining project, which will also eliminate the need for carbon tetrachloride and is to be funded by Albuquerque. Plant management could also view their recently approved project to recycle the same machine coolants as a more cost effective method to achieve waste minimization more quickly. 

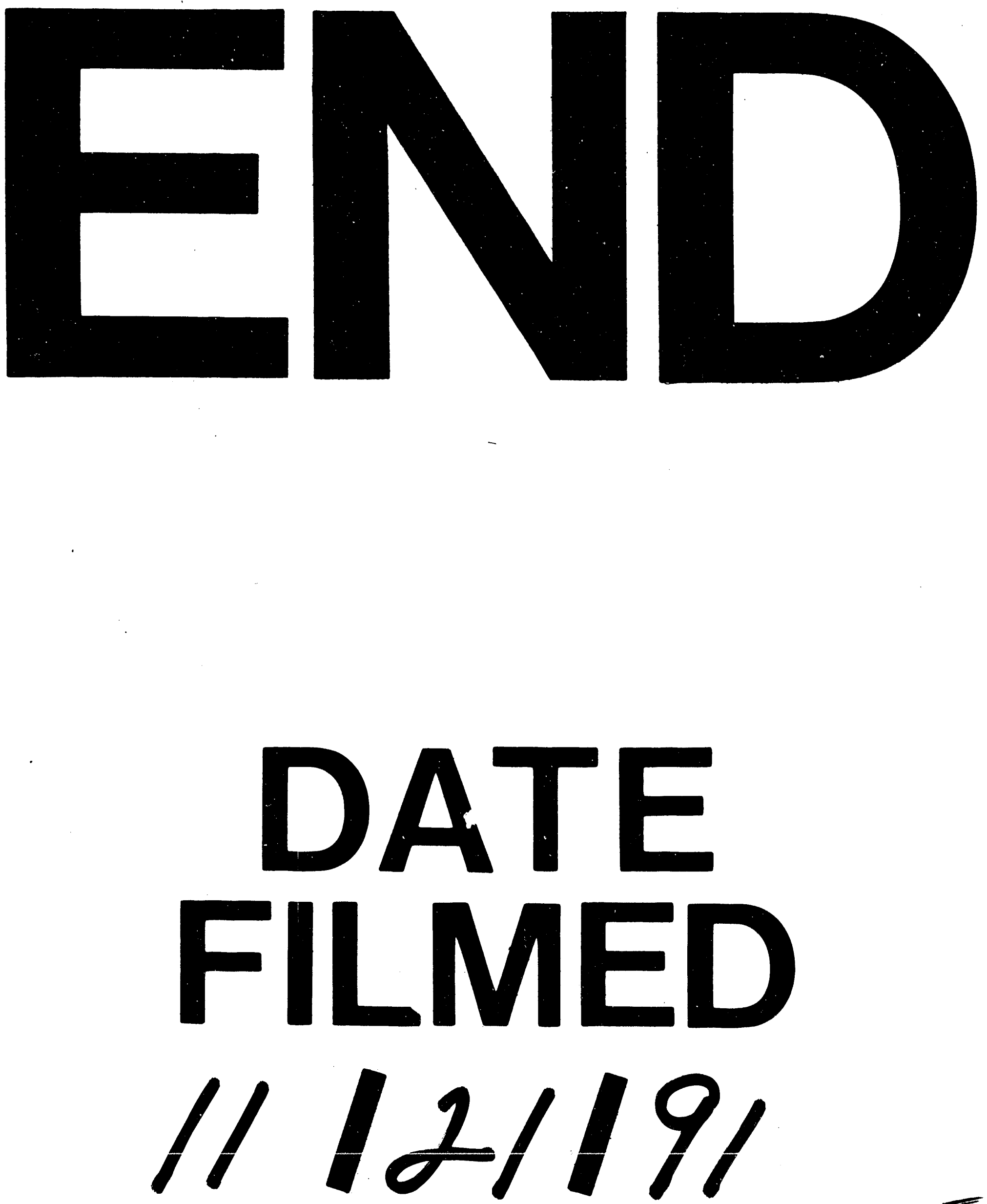

II 
